\title{
Incomplete asset markets and the cross-country consumption correlation puzzle
}

\author{
Robert Kollmann \\ Département des Sciences Economiques, Unitersité de Montréal, Montréal, Qué. H3C 3J7. Canada
}

(Received May 1992; final version received June 1995)

\begin{abstract}
Recent International Real Business Cycle (IRBC) models that assume complete international asset markets generate cross-country consumption correlations that are too high, when compared to the data. This paper shows that an IRBC model in which asset markets are incomplete (in the sense that only debt contracts can be traded in asset markets) can generate cross-country consumption correlations that are markedly lower. This improvement is achieved without significantly worsening predictions for other key business cycle statistics.
\end{abstract}

Key words: Incomplete asset markets; Risk sharing; Business cycles; Consumption JEL classification: $\mathrm{E} 32 ; \mathrm{F} 41 ; \mathrm{G} 15$

\section{Introduction}

In recent years, much effort has been devoted to extending the closed economy Real Business Cycle (RBC) model to an international setting; see

\footnotetext{
This paper is based on a chapter of my Ph.D. dissertation at the University of Chicago. I thank Michael Woodford, John Huizinga, José Scheinkman, Mathew Canzoneri, Jean-Pierre Danthine, Chris Erceg, Christophe Faugère, Robert Hodrick, Allan Head, Thomas Lemieux, Youngjae Lim. John Matsusaka, Enrique Mendoza, Michael Mussa, and Kei-Mu Yi for advice. I am particularly grateful to Michael Woodford for his guidance and to Patrick Kehoe for detailed suggestions. Thanks are also extended to the editor and the referee for detailed comments as well as to Lea-Anne Solomonian for editorial assistance. Financial support from the Bradley Foundation, the International Economic Workshop at the University of Chicago (supported by a grant from the Sloan Foundation), as well as from Fonds Marcel Faribault and Fonds CAFIR at Universite de Montréal is gratefully acknowledged.
} 
McCallum (1989) and Danthine and Donaldson (1993) for surveys of the RBC literature. Authors such as Backus, Kehoe, and Kydland (1992), Crucini (1989), and Baxter and Crucini (1993) have developed two-country RBC models. ${ }^{1}$ In these models, each country is inhabited by a representative agent. Countries interact by trading in goods markets and in financial markets. A central assumption in this recent work is that there exist complete international asset markets.

A striking shortcoming of available models of this type is that they tend to generate cross-country consumption correlations that are too high when compared to actual data. For example, different versions of the seminal two-country RBC model presented by Backus et al. (1992) produce cross-country consumption correlations in the range 0.69 to 0.95. In contrast, Backus et al. report that the correlation of (detrended) consumption in the United States and in an aggregate of European countries equals 0.46 .

This study investigates whether an International RBC (IRBC) model with incomplete asset markets can change this prediction. The paper is motivated by the conjecture that the high cross-country consumption correlations generated by existing two-country $\mathrm{RBC}$ models reflect the assumption that asset markets are complete. After all, complete asset markets allow consumers to engage in extensive international risk pooling.

In this paper, a two-country RBC model is presented in which international asset markets are incomplete in the sense that only debt instruments (risk-free bonds) can be used in international financial transactions. This structure of (incomplete) asset markets underlies permanent income models of consumption behavior and has also been used in much recent theoretical and applied work on small open economies (see, e.g., Cardia, 1991; Mendoza, 1991).

The elimination of trade in state-contingent assets limits international risk sharing. A country affected by an idiosyncratic (country-specific) income shock can mitigate the effect of this shock on its consumption by trading in bonds. One may expect, however, that countries are less able to offset the effects of idiosyncratic income shocks when markets are incomplete than when markets are complete. Hence, one expects that consumption is less closely correlated across countries when markets are incomplete than in an Arrow-Debreu world.

The paper confirms this intuition. It shows that an IRBC model with incomplete asset markets can generate cross-country consumption correlations that are markedly lower, and hence closer to the data, than those that obtain when complete asset markets are assumed. The assumption of incomplete asset markets also leads to improved predictions for other international

\footnotetext{
${ }^{1}$ Models of this type have also been studied by Dellas (1986), Cantor and Mark (1988), Finn (1990), Stockman and Tesar (1990), Backus and Smith (1992), Costello and Prashnik (1992), Devereux et al. (1992), Ravn (1992), Reynolds (1992), Boileau (1993), Canova (1993), Yi (1993), and Bec (1994).
} 
comovements (for example, the incomplete markets model captures better the countercyclical behavior of net exports). These improvements are not achieved at the cost of significantly poorer predictions for other key business cycle statistics.

Section 2 of the paper presents the two-country model with incomplete markets. Section 3 briefly discusses an IRBC model with complete asset markets. Stylized facts about international business cycles are discussed in Section 4. Simulation results are presented in Section 5. Section 6 concludes.

\section{A two-country business cycle model with incomplete asset markets}

\subsection{Preferences and technologies}

The model considered in this paper follows rather closely the structure of earlier two-country RBC models (see, in particular, the models of Backus et al., 1992; Baxter and Crucini, 1993), except that here incomplete asset markets are assumed.

A world with two countries, indexed by $i=1,2$, is considered. Each country is inhabited by a representative consumer. There is a single good produced and consumed by both countries and also used as an investment good. There are no transportation costs or tariffs. Hence, there are no constraints on international flows of goods. Labor, however, is immobile internationally. The preferences of country i's representative consumer are given by

$$
V_{t}^{i}=\mathrm{E}_{t} \sum_{\tau=0}^{\infty} \beta^{\tau} u\left(C_{t+\tau}^{i}, L_{t+\tau}^{i}\right)
$$

where $C_{t+\tau}^{i}$ is $i$ 's consumption at date $t+\tau$ and $L_{t+\tau}^{i}$ is the number of hours worked. $0<\beta<1$ is the country's subjective discount factor. $\mathrm{E}_{t}$ denotes expectations conditional on period $t$ information. The period utility function $u$ is of the form

$$
u(C, L)=(1 /(1-\sigma)) \cdot\left[\left(C \cdot(1-L)^{\mu}\right)^{1-\sigma}-1\right] .
$$

$\mu>0$ and $\sigma>\mu /(1+\mu)$ are assumed in order to ensure that utility is increasing in $C$, decreasing in $L$, and strictly concave. In Eq. (2), the number of hours available to the representative agent at a given date has been normalized to one, so that $1-L$ represents the leisure of the agent.

Country $i$ 's output in period $t$ is given by

$$
Y_{t}^{i}=\theta_{t}^{i} \cdot\left(K_{t}^{i}\right)^{1-\eta} \cdot\left(L_{t}^{i}\right)^{\eta}
$$


Here, $\theta_{t}^{i}$ is an exogenous productivity index and $K_{t}^{i}$ is country $i$ 's capital stock. The law of motion of capital is

$$
K_{t+1}^{i}+\phi\left(K_{t+1}^{i}, K_{t}^{i}\right)=(1-d) \cdot K_{t}^{i}+I_{t}^{i}
$$

where $I_{t}^{i}$ denotes how much output is required to change the capital stock from $K_{t}^{i}$ to $K_{t+1}^{i} .0 \leq d \leq 1$ is the depreciation rate of the capital stock and $\phi(.,$.$) is$ a convex adjustment cost function that is homogeneous of degree one in $K_{t+1}^{i}$ and $K_{t}^{i}$ :

$$
\phi\left(K_{t+1}^{i}, K_{t}^{i}\right)=0.5 \cdot \Phi \cdot\left\{K_{t+1}^{i}-K_{t}^{i}\right\}^{2} / K_{t}^{i}, \quad \Phi>0
$$

\subsection{The structure of asset markets}

The key difference between the present model and standard IRBC models is that only risk-free one-period real debt contracts can be used in financial markets. Besides the fact that labor is immobile internationally, this is the only restriction on international transactions that will be assumed. The assumption that agents' financial transactions are restricted to risk-free bonds is a key assumption in permanent income models of consumption behavior (see, e.g., Sargent, 1987, Ch. 12). This asset markets structure has also been assumed in much recent theoretical and applied work on small open economies. ${ }^{2}$

Interesting alternatives to the incomplete markets structure discussed in the present paper might be structures where debt contracts and a limited set of state-contingent assets, such as stocks (residual claims), can be traded internationally (see, e.g., Cole, 1988). Because of its simplicity, the model with pure borrowing and lending will provide a useful benchmark for research on these more complex asset market structures. In recent monetary open economy models (see, e.g., Grilli and Roubini, 1991; McCurdy and Ricketts, 1991; Schlagenhauf and Wrase, 1992), agents face cash-in-advance constraints for their consumption purchases. Constraints of this type too could help to reduce the cross-country consumption correlation compared to the correlations that obtain in an Arrow-Debreu world.

With asset transactions restricted to one-period bonds, country i's budget constraint in period $t$ is

$$
C_{t}^{i}+I_{t}^{i}+A_{t}^{i}=Y_{t}^{i}+\left(1+r_{t-1}\right) \cdot A_{t-1}^{i},
$$

\footnotetext{
${ }^{2}$ See, e.g., Ghosh (1990), Leiderman and Razin (1990), Sheffrin and Woo (1990), Cardia (1991), Mendoza (1991), Glick and Rogoff (1992), Otto (1992), Bruno and Portier (1993), Macklem (1993), Schmitt-Grohé (1993), and van Wincoop and Marrinan (1993).
} 
where $A_{t-1}^{i}$ is the country's (net) stock of one-period bonds that become due in period $t$ and $r_{t-1}$ is the real interest rate on these bonds $\left(A_{t-1}^{i}>0\right.$ if the country is a lender).

Country i's decision problem is to maximize the lifetime utility defined in (1) subject to the constraint that the budget constraint (6) holds in all periods and for all states of the world. First-order conditions for this decision problem are provided in the Appendix.

Given exogenous productivity processes $\left\{\theta_{t}^{i}\right\}$ for $i=1,2$ an equilibrium with incomplete asset markets is a set of stochastic processes for the endogenous variables $\left\{C_{t}^{i}, L_{t}^{i}, K_{t}^{i}, A_{t}^{i}, r_{t}\right\}$ for $i=1,2$ that satisfies the first-order conditions listed in the Appendix and the budget constraints of the two countries, as well as the condition that the bond market clears:

$$
A_{t}^{1}+A_{t}^{2}=0 \text { for all } t .
$$

By Walras' law, equilibrium in the loan market implies that the goods market clears as well.

\subsection{The solution method}

An approximate solution of the model is obtained by taking a linear approximation of the equilibrium conditions around a deterministic steady state (i.e., around an equilibrium in which all endogenous and exogenous variables are constant). ${ }^{3}$ This approximation yields a system of expectational difference equations that is solved using the method outlined in Blanchard and Kahn (1980).

\section{Complete asset markets}

The source of uncertainty in the model is given by exogenous shocks to total factor productivity. With complete asset markets (Arrow-Debreu markets), agents can trade claims with pay-offs that are contingent on these productivity shocks. This structure of asset markets guarantees that competitive equilibria are Pareto optimal. Pareto optima can be found by imagining that in some 'initial' period $t=0$, the following planning problem is solved:

Maximize $\lambda \cdot V_{0}^{1}+(1-\lambda) \cdot V_{0}^{2}$,

\footnotetext{
${ }^{3}$ This solution method is standard in the RBC literature (see, e.g., King et al., 1988, 1990; Rotemberg and Woodford, 1989; Kollmann, 1991). In the simulations reported below, the model is linearized around a symmetric deterministic steady state in which all variables have the same values in both countries.
} 
subject to the constraint that the following world resource constraint holds in all periods $t \geqslant 0$ and for all states of the world:

$$
C_{t}^{1}+C_{t}^{2}+I_{t}^{1}+I_{t}^{2}=Y_{t}^{1}+Y_{t}^{2} .
$$

In (8), $V_{0}^{i}$ is country $i$ 's expected lifetime utility at date $t=0$ [see Eq. (1)]. The weights $\lambda$ and $1-\lambda$ (with $0<\lambda<1$ ) reflect the wealth of the two countries (see, e.g., Rebelo, 1988a, b).

One of the first-order conditions of this planning problem is that marginal utilities in the two countries [weighted by $\lambda$ and $(1-\lambda)$, respectively] are equated (for discussions of this condition see, e.g., Scheinkman, 1984; Leme, 1984; Kollmann, 1991, 1995). When the utility function (2) is assumed, this risk sharing condition can be expressed as

$$
\lambda \cdot\left(C_{t}^{1}\right)^{-\sigma} \cdot\left(1-L_{t}^{1}\right)^{\mu \cdot(1-\sigma)}=(1-\lambda) \cdot\left(C_{t}^{2}\right)^{-\sigma} \cdot\left(1-L_{t}^{2}\right)^{\mu \cdot(1-\sigma)} .
$$

In the special case where labor supplies are fixed, this condition implies that $c_{t}^{1}=A \cdot c_{t}^{2}$, where $\Lambda>0$ is a constant. In other words, then consumption is perfectly positively correlated across countries. The same prediction obtains also when $\sigma=1$ (even when hours are variable) as then the period utility function is additively separable in consumption and hours (which implies that variations in hours do not affect the marginal utility of consumption). ${ }^{4}$ When hours vary and/or the utility function is nonseparable, then the cross-country consumption correlation is smaller than unity, even when asset markets are complete.

The risk sharing condition (10) implies also that intertemporal marginal rates of substitution in consumption are equated across countries, and that for all possible states of the world (see, e.g., Obstfeld, 1993). In contrast, when asset markets are incomplete, then intertemporal marginal rates of substitution are merely equated in expected value. ${ }^{5}$ As a result, one suspects that consumption is less closely correlated across countries when asset markets are incomplete.

In the simulations of the model with complete asset markets reported below, equal welfare weights are attached to the two countries. The linear approximation method described in Section 2.3 is used to solve numerically the complete markets model.

\footnotetext{
${ }^{4}$ When $\sigma=1$, the utility function (2) becomes $u(C, L)=\ln (C)+\mu \cdot \ln (1-L)$.

${ }^{5}$ As the Fuler condition (A.1) in the Appendix holds for $i=1,2$, one sees that $\beta \cdot \mathrm{E}_{t} u_{1}\left(C_{t+1}^{1}, L_{t+1}^{1}\right) / u_{1}\left(C_{t}^{1}, L_{t}^{1}\right)=\beta \cdot \mathrm{E}_{t} u_{1}\left(C_{t+1}^{2}, L_{t+1}^{2}\right) / u_{1}\left(C_{t}^{2}, L_{t}^{2}\right)$, where $u_{1}$ denotes the marginal utility of consumption. In contrast, $\beta \cdot u_{1}\left(C_{t+1}^{1}, L_{t+1}^{1}\right) / u_{1}\left(C_{t}^{1}, L_{t}^{1}\right)=\beta \cdot u_{1}\left(C_{t+1}^{2}, L_{1+1}^{2}\right) / u_{1}\left(C_{t}^{2}, L_{t}^{2}\right)$ holds when asset markets are complete.
} 


\section{Stylized facts on international business cycles}

The column labeled 'Data' in Table 1 presents key statistics that describe the properties of quarterly macroeconomic time series for the G-7 countries. The sample period is 1970:1-1991:3. All statistics are based on series that were detrended using the Hodrick and Prescott (1980) filter (henceforth, HP filter). Except for series on the ratio of net exports to output, logarithms of all series were taken before applying the HP filter. To save space, only average statistics for the G-7 countries are reported; Backus et al. (1992) and Kollmann (1991) present more detailed descriptive statistics on international business cycles. For example, the cross-country correlations reported in the 'Data' column are averages of cross-country correlations computed for all pairs of G-7 countries (data sources and the definitions of the variables used to construct the statistics in the 'Data' column are provided in the Appendix).

For the G-7 countries, the (average) cross-country correlations of output, of consumption, and of investment are $0.46,0.34$, and 0.45 , respectively. ${ }^{6}$ Domestic investment is closely correlated with domestic saving. It can also be seen that investment is more volatile than output, while hours worked and consumption are less volatile than output. These variables are all highly serially correlated. Consumption, investment, and hours are strongly procyclical (positively correlated with output), while net exports are countercyclical. These stylized facts on cyclical fluctuations do not depend on the HP filter; other detrending methods (e.g., linear detrending) lead to similar empirical regularities.

\section{Simulations}

\subsection{The parameters of the model}

The depreciation rate $d$ is set to 0.021 , which corresponds to the quarterly depreciation rate estimated by Christiano and Eichenbaum (1992) using postwar U.S. data. In the model, the share of output going to labor is given by the parameter $\eta$. For the U.S., the average value of the ratio of the compensation of employees to GDP (net of indirect taxes) is approximately 0.64 (similar values obtain for the other countries in the sample) and, hence, $\eta=0.64$ is assumed. As is common in the RBC literature (e.g., King et al., 1988), the steady state interest rate is set equal to the observed average real return on equity. As documented by Mehra and Prescott (1985), the long-run average annual real return on equity in the U.S. is $7 \%$ and, hence, $r=0.0175$ is used (as the model is calibrated to

\footnotetext{
'The empirical consumption measure used in the 'Data' column is private consumption of nondurables and services.
} 
quarterly data). ${ }^{7}$ These (or very similar) values of $\delta, \eta$, and of the steady state interest rate are generally used in RBC models. The adjustment cost parameter $\Phi$ is set to $\Phi=3$ in order to match the observation that the standard deviation of investment is approximately 3.3 times as large as that of output (for lower values of $\Phi$, investment is excessively volatile). ${ }^{8}$

As is common in the RBC literature (see, e.g., Prescott, 1986; Hansen and Wright, 1992), the preference parameter $\mu$ is selected in such a way that, in steady state, agents devote one-third of their time to work, which requires $\mu=1.59$ (empirical studies on the allocation of time suggest that adults in industrialized countries devote roughly one-third of their nonsleeping time to market work; see Juster and Stafford, 1991).

The baseline case assumes that the coefficient of relative risk aversion is $\sigma=2$. This value lies in the range of risk aversion coefficients usually assumed in RBC studies (Friend and Blume, 1975, present empirical evidence suggesting that the relative risk aversion coefficient is in the range of 2; other estimates of that coefficient lie between 0 and 5 - see, e.g., Hansen and Singleton, 1983; Dunn and Singleton, 1986).

Productivity follows a vector autoregressive process:

$$
z_{t}=R \cdot z_{t-1}+\varepsilon_{t}
$$

where $z_{t}=\left(\ln \left(\theta_{t}^{1}\right), \ln \left(\theta_{t}^{2}\right)\right)^{\prime}$ is the vector of productivities in the two countries, expressed in logs. The vector $\varepsilon_{t}=\left(\varepsilon_{t}^{1}, \varepsilon_{t}^{2}\right)^{\prime}$ is i.i.d. with mean zero and covariance matrix $\Omega$. The simulations assume

$$
R=\left[\begin{array}{cc}
0.95 & 0 \\
0 & 0.95
\end{array}\right] \text { and } \Omega=0.007^{2} \cdot\left[\begin{array}{cc}
1 & 0.2 \\
0.2 & 1
\end{array}\right]
$$

As is common in the RBC literature, productivity is thus assumed to be highly serially correlated. ${ }^{9}$ This specification inplies that the cross-country productivity correlation is $0.20 .^{10}$.

\footnotetext{
${ }^{7}$ This requires that $\beta=0.9828$ is assumed, as $\beta \cdot(1+r)=1$ holds in steady state

${ }^{8}$ It appears that, for this value of $\Phi$, the average capital adjustment cost amounts to less than $0.01 \%$ of output.

${ }^{9}$ Prescott (1986) presents evidence that the autocorrelation of productivity is in the range of 0.95 , and RBC studies usually use this value or one close to it (e.g., Hansen, 1985; Gomme, 1993; Ambler and Paquet, 1994). Hence, an autocorrelation of 0.95 is assumed in this study. The standard deviation of the productivity innovation in country $i\left(\varepsilon_{t}^{i}\right)$ is set to 0.007 , as this is approximately the value for the standard deviation of productivity innovations suggested by Prescott (1986). To check whether the $R$ matrix assumed in (12) is consistent with the data, (11) was fitted for all pairs of G-7 countries (using the productivity series described in the Appendix; a linear time trend was also included in the regressions). The estimated $R$ matrices are generally compatible (at conventional significance levels) with (12).

${ }^{10}$ For the $G-7$ countries, the average cross-country correlation of HP filtered total factor productivity is 0.25 (for linearly detrended productivity, the average correlation is 0.22 ).
} 


\subsection{Simulation results}

Tables 1 and 2 report the simulation results. The model statistics reported in the tables are averages of moments calculated for 1000 simulations with a sample length of 87 periods each (this number of periods corresponds to the length of the empirical data set). All simulated series were passed through the HP filter before the model statistics were computed.

To formally evaluate how close the predicted statistics are to the data, the methodology developed by Gregory and Smith (1991) was used. The proportion of the 1000 simulations was determined in which the cross-country consumption correlation generated by the model was smaller than the empirical consumption correlation of 0.34 . Let $\pi$ denote this fraction of trials. $\pi$ and $1-\pi$ can be interpreted as probability values for one-sided tests of the hypothesis that the cross-country consumption correlation generated by the model is compatible with the data (values of $\pi$ close to zero or to unity indicate a rejection of this hypothesis). ${ }^{11}$

Table 1 considers the baseline specification. The cross-country consumption correlation is 0.72 when markets are complete and 0.38 when markets are incomplete. The associated Gregory-Smith probability values are $\pi=0.00$ (complete markets) and $\pi=0.40$ (incomplete markets). When asset markets are incomplete, the cross-country consumption correlation is thus significantly closer to the data.

Table 1 shows that the assumption of incomplete asset markets also leads to improved predictions for other international comovements. For example, the correlation between net exports and output is markedly lower (and closer to the data) when markets are incomplete. Like previous IRBC models that assume a single good (e.g., Backus et al., 1992), the present model underpredicts the cross-country correlations of output, investment, and hours worked (Stockman and Tesar, 1990, show that an IRBC model with multiple goods can generate cross-country output correlations that are more consistent with the data). The assumption of incomplete markets does not overcome this shortcoming. However, cross-country correlations of output, investment, and

\footnotetext{
${ }^{11}$ The Gregory and Smith (1991) methodology was also used to compute $95 \%$ confidence intervals for each of the statistics considered in Tables 1 and 2 (these intervals run from the 0.025 to the 0.975 quantiles of the frequency distribution of the simulated statistics that obtain when the model is simulated 1000 times). In the tables, a $\dagger$ next to a theoretical statistic indicates that the $95 \%$ confidence interval for the statistic includes the empirical moments reported in the 'Data' column.
} 
Table 1

Properties of baseline model

$\begin{array}{llll}\text { Statistics } & \begin{array}{l}\text { Incomplete } \\ \text { markets }\end{array} & \begin{array}{l}\text { Complete } \\ \text { markets }\end{array} & \text { Data }\end{array}$

Standard deviations (in \%)

Output

Standard deviations relative to output

Consumption

$\begin{array}{lll}0.47 \dagger & 0.40 & 0.50 \\ 3.35 \dagger & 3.57 \dagger & 3.37 \\ 0.36 & 0.43 & 0.74 \\ 0.14 \dagger & 0.17 & 0.10\end{array}$

Hours worked

$0.14 \dagger$

0.10

Autocorrelations

Output

$0.68 \dagger$

$0.68+$

0.78

Consumption

$0.68 \dagger$

$0.69+$

0.81

Investment

$0.66^{+}$

$0.66 t$

0.79

Hours worked

$0.68 \dagger$

$0.68 \dagger$

0.75

Net exports/output

0.87

0.94

0.71

Cross-correlations with output

Consumption

$\begin{array}{crr}0.98 & 0.91 & 0.73 \\ 0.96 & 0.96 & 0.80 \\ 0.98 & 0.96 & 0.59 \\ -0.07 \dagger & 0.17 & -0.23 \\ 0.97 & 0.97 & 0.78\end{array}$

Investment

Hours worked

Net exports/output

Saving-investment correlations

0.78

Cross-country correlations

Consumption

$\begin{array}{rrr}0.38 \dagger & 0.72 & 0.34 \\ 0.10 \dagger & 0.00 & 0.46 \\ -0.12 & -0.29 & 0.45 \\ -0.12 & -0.44 & 0.40\end{array}$

Output

Investment

Hours worked

$-0.12$

0.40

The 'Data' column reports empirical statistics for the G-7 countries. See the Appendix for detailed informations on the data. 'Standard deviations relative to output' are standard deviations of consumption, investment, etc. divided by standard deviation of output. 'Net exports/output' is ratio of net exports to output.

The statistics in columns 1 and 2 are averages over 1000 simulations of 87 periods each. All statistics are based on HP filtered series.

$\dagger$ indicates that a $95 \%$ confidence interval includes the empirical statistic reported in the 'Data' column (the $95 \%$ confidence intervals run from the 0.025 to the 0.975 quantiles of the frequency distribution of the simulated statistics). 
hours are larger (and hence closer to the data) when asset markets are incomplete. $^{12}$

Assuming incomplete markets have a fairly weak effect on the remaining statistics considered in Table 1. Some predictions worsen somewhat, while others improve slightly. ${ }^{13}$ For example, the relative standard deviation of hours, which is already too low when markets are complete, falls somewhat when incomplete markets are assumed. On the other hand, the relative standard deviation of consumption, which likewise is too small when asset markets are complete, increases when risk sharing is restricted. Note also that, as the two-country RBC model of Baxter and Crucini (1993), the present model predicts that, within the same country, saving is closely correlated with investment (this prediction obtains irrespective of the structure of asset markets).

\section{Alternative specifications}

Table 2 changes the model specification compared to the baseline case. ${ }^{14}$ The columns labeled 'Fixed hours' in Table 2 assume that labor supplies are fixed. It seems interesting to consider the 'Fixed hours' case hecause, as discussed above, the complete markets model predicts that consumption is perfectly correlated across countries when labor supplies are fixed. Table 2 shows that, in contrast, the cross-country consumption correlation is 0.51 when markets are incomplete (the associated Gregory-Smith probability value is $\pi=0.11$ ). It thus appears again that assuming incomplete asset markets leads to a marked reduction of the cross-country consumption correlation.

It also seems interesting to vary the risk aversion coefficient. In the columns labeled 'High risk aversion' the risk aversion coefficient is raised to $\sigma=5$. For both asset market structures, this lowers the cross-country consumption

\footnotetext{
${ }^{12}$ To get an intuition for these findings, consider the effects of an increase in productivity that occurs, say, in country1. Simulations show that hours worked and investment increase in country 1. Also, the interest rate rises, which lowers country 2 investment (hence, the negative cross-country investment correlations reported in Table 1 ). When markets are complete, the country 1 productivity shock induces a positive wealth effect in country 2 which implies that country 2 hours fall (i.e., the sign of the response of hours worked differs in the two countries). When markets are incomplete, this other-country wealth effect is not present. In addition, country 1 wealth rises more strongly when markets are incomplete, which dampens the rise in country 1 hours and strengthens the rise in country 1 consumption. This explains why net exports are more countercyclical and why the cross-country hours correlation is higher when markets are incomplete (the higher cross-country hours correlation helps explain why the cross-country correlations of output and investment are higher when markets are incomplete).

${ }^{13}$ But most of the other statistics are basically unaffected when incomplete markets are assumed.

${ }^{14}$ To save space, Table 2 only reports cross-country correlations of consumption and output. The remaining predictions are, on the whole, rather similar to those which obtain in the baseline casc (detailed simulation results are available on request).
} 
Table 2

Properties of alternative economics

\begin{tabular}{|c|c|c|c|c|c|}
\hline \multirow[b]{3}{*}{ Statistics } & \multicolumn{4}{|c|}{ Model specification } & \multirow[b]{3}{*}{ Data } \\
\hline & \multicolumn{2}{|l|}{ Fixed hours } & \multicolumn{2}{|c|}{ High risk aversion } & \\
\hline & $\begin{array}{l}\text { Incomplete } \\
\text { markets }\end{array}$ & $\begin{array}{l}\text { Complete } \\
\text { markets }\end{array}$ & $\begin{array}{l}\text { Incomplete } \\
\text { markets }\end{array}$ & $\begin{array}{l}\text { Complete } \\
\text { markets }\end{array}$ & \\
\hline \multicolumn{6}{|c|}{ Cross-country correlations } \\
\hline Consumption & $0.51 \uparrow$ & 1.00 & $0.28 \dagger$ & $0.55 \dagger$ & 0.34 \\
\hline Output & $0.18 \dagger$ & $0.17 \dagger$ & $0.14 \dagger$ & 0.04 & 0.46 \\
\hline
\end{tabular}

The columns labeled 'Fixed hours' assume that labor supply is completely inelastic. The 'High risk aversion' experiment assumes $\sigma=5$.

$\dagger$ indicates that a $95 \%$ confidence interval includes the cmpirical statistic reported in the 'Data' column (the $95 \%$ confidence intervals run from the 0.025 to the 0.975 quantiles of the frequency distribution of the simulated statistics). See Table 1 for additional explanations.

correlation compared to the baseline case. ${ }^{15}$ However, the cross-country consumption correlation remains markedly lower when markets are incomplete $(0.28)$ than when markets are complete $(0.55) .{ }^{16}$

\section{Concluding remarks}

This paper has presented a two-country RBC model in which asset markets are incomplete - in the sense that only debt contracts can be traded in international financial markets. The model can generate cross-country consumption correlations that are markedly lower, and hence closer to the data, than the cross-country consumption correlations that obtain when asset markets are complete.

\footnotetext{
${ }^{15}$ When $\sigma$ is raised, variations in hours worked have a stronger impact on the marginal utility of consumption [note: the elasticity of the marginal utility of consumption with respect to hours is $-\mu \cdot(1-\sigma) \cdot L /(1-L)]$. As hours fluctuations have a large country-specific component, this helps explain why consumption comoves less closely in the two countries when $\sigma$ is raised.

${ }^{16}$ The associated Gregory-Smith (1991) probability values are $\pi=0.60$ (incomplete markets) and $\pi=0.08$ (complete markets).
} 


\section{Appendix}

\section{A.1. The model with incomplete asset markets: First-order conditions}

Ruling out Ponzi schemes, the solution of the decision problem of country $i$ satisfies the following Euler conditions:

$$
\begin{aligned}
& u_{1, t}^{i}=\left(1+r_{t}\right) \cdot \beta \cdot \mathrm{E}_{t} u_{1, t+1}^{i}, \\
& u_{1, t}^{i}=\beta \cdot \mathrm{E}_{t} M P K_{\mathrm{t}+1}^{i} \cdot u_{1, t+1}^{i} .
\end{aligned}
$$

Here $M P K_{t+1}^{i} \equiv\left[f_{1, t+1}^{i}+1-d-\phi_{2, t+1}^{i}\right] /\left[1+\phi_{1, t}^{i}\right]$ is country i's intertemporal marginal rate of transformation between output in periods $t$ and $t+1$, while $u_{s, t}^{i}, f_{s, t}^{i}$, and $\phi_{s, t}^{i}$ denote the derivatives of $u\left(C_{t}^{i}, L_{t}^{i}\right), f\left(K_{t}^{i}, L_{t}^{i}, \theta_{t}^{i}\right) \equiv$ $\theta_{t}^{i} \cdot\left(K_{t}^{i}\right)^{1-\eta} \cdot\left(L_{t}^{i}\right)^{\eta}$, and $\phi\left(K_{t+1}^{i}, K_{t}^{i}\right)$ with respect to the sth argument of these functions. In addition, country $i$ equates its marginal rate of substitution between labor and consumption to the marginal product of labor:

$$
u_{2, t}^{i}+\left[\theta_{t}^{i} \cdot\left(K_{t}^{i}\right)^{1-\eta} \cdot \eta \cdot\left(L_{t}^{i}\right)^{\eta-1}\right] \cdot u_{1, t}^{i}=0 .
$$

\section{A.2. Data appendix}

The 'Data' column of Tables 1 and 2 reports statistics that are averages of empirical statistics computed for the G-7 countries. For example, the withincountry statistics reported in the 'Data' column are arithmetic averages of statistics computed for each of the G-7 countries (e.g., the empirical statistic for consumption reported under the subheading 'Standard deviations relative to output' was obtained by computing the ratio of the standard deviation of consumption to the standard deviation of output for each G-7 country and taking the average value of this ratio for the G-7 countries). Empirical crosscountry correlations reported in the 'Data' column are averages of crosscountry correlations computed for all pairs of G-7 countries.

Empirical series used for statistics reported in 'Data' column of Tables 1 and 2: output - GDP; consumption - private sector consumption of nondurables plus services; investment - gross fixed capital formation; net exports - exports of goods and services minus imports of goods and services; saving - GDP minus total private consumption minus government consumption (in model, saving defined as $Y-C$ ). All empirical variables are quarterly (1970:1-1991:3); they are in per capita terms and in constant prices.

\section{Data sources and definition of variables}

GDP, Gross Fixed Capital Formation, Government Consumption, Total Private Consumption, Exports of Goods and Services, Imports of Goods and Services: 
These series are taken from International Financial Statistics (IFS). They are provided in current prices by IFS. The series were deflated using the IFS consumer price index. The investment series include public investment.

Private Consumption of Nondurables and Services: Expenditures on nondurables and services (in constant prices) from OECD Quarterly National Accounts.

Hours of Work: The following series were used. U.S. - total employee hours (from establishment survey) were taken from Citibase (series LPMHU). Japan, France - an index of total hours worked was constructed by multiplying the series 'paid employment in nonagricultural establishments' and 'weekly hours of work in the nonagricultural sector' from the Bulletin of Labour Statistics published by the International Labour Office (ILO) (for Japan, the hours series for employees was used). United Kingdom - total employment multiplied by average weekly hours worked (from Employment Gazette, Supplement with Historical Statistics, 1992). This source provides hours data at annual frequency only. A quarterly U.K. hours series was constructed by linear interpolation. Italy - total employment (not hours) in nonagricultural sector (from ILO). Canada - 1975-1991: total hours worked (all jobs); before 1975: total employment (series from Historical Labour Force Statistics 1991, Statistics Canada).

Capital Stock: U.S. - private plus government owned fixed capital (at constant cost); source for 1971-1990: Musgrave (1992, Table 4). The U.S. capital stock for 1991 was estimated by assuming that the growth rate of capital between 1990 and 1991 equaled the average growth rate during 1971-1990. Japan, Germany, France, U.K., Canada - for 1971-1989, data on total net stocks of capital in constant prices were taken from Flows and Stocks of Fixed Capital (OECD). Italy - 1971-1985 capital stock data in constant prices were taken from the Intersectoral Database (OECD). The Italian capital stock for 1986-1989 was estimated by assuming that during each of these four years the share of Italian physical capital in the total capital stock of the G-7 countries (other than the U.S.) equaled the share observed in 1985. Capital stocks for 1990-1991 were estimated by assuming that for each country the growth rate of the capital stock between 1989 and 1991 equaled the average growth rate of capital in that country during the period 1971-1989. All capital stock data from these sources are annual. Quarterly capital stock series were constructed by linear interpolation.

Population: International Financial Statistics. Quarterly series were constructed from annual figures using linear interpolation.

Total Factor Productivity: TFP series were obtained according to the method described in Solow (1957). For this purpose, the GDP, capital stock, and hours series described above were used, as well as time series for the share of labor earnings in output. The latter were constructed as follows: for each country, data from the OECD National Accounts were used to construct an annual series (for 1970-1991) for the ratio (compensation of employees paid by 
resident producers) $\div$ (GDP minus indirect taxes plus subsidies). To obtain a quarterly labor share, it was assumed that the labor share is constant during all quarters of the same year.

Series that are not provided in seasonally adjusted form by the data sources were adjusted with the Census X-11 seasonal adjustment procedure (using the EZ-X11 program available from Doan Associates, Evansion, IL).

\section{References}

Ambler, S. and A. Paquet, 1994, Stochastic depreciation and the business cycle, International Economic Review 35, 101-116.

Backus, D. and G. Smith, 1992, Consumptions and real exchange rates in dynamic exchange economies with non-traded goods, Manuscript (Economics Department, Queen's University, Kingston).

Backus, D., P. Kehoe, and F. Kydland, 1992, International real business cycles, Journal of Political Economy 100. 745-775.

Baxter, M. and M. Crucini, 1993, Explaining saving and investment correlations. American Economic Review 83, 416-436.

Bec, F., 1994. La transmission internationale des fluctuations, Revue Economique 45, 89114.

Blanchard, O. and C. Kahn, 1980, The solution of linear difference models under rational expectations, Econometrica 48, 1305-1311.

Boileau, M., 1993, Growth and the international transmission of business cycles, Manuscript (Economics Department, Queen's University, Kingston).

Bruno, C. and F. Portier, 1993, Cycle réel, représentation VAR et ouverture de l'économie française. Observations et Diagnostiques Economiques 45, 245-281.

Canova. F., 1993, Sources and propagation of international business cycles: Common shocks or transmission. Discussion paper no. 781 (Center for Economic Policy Research, London).

Cantor, R. and N. Mark, 1988, The international transmission of real business cycles. International Economic Review 29, 493-507.

Cardia. E., 1991, The dynamics of a small open economy in response to monetary, fiscal, and productivity shocks. Journal of Monetary Ecnomics 28. 411-434.

Christiano, L. and M. Eichenbaum, 1992, Current real-business cycle theories and aggregate labor-market fluctuations, American Economic Review 82, 430-450.

Cole. H., 1988. Financial structure and international trade, International Economic Review 29. $237-259$.

Costello, D. and J. Prashnik, 1992, The role of oil price shocks in a two-sector, two-country model of the business cycle, Manuscript (University of Florida, Gainesville, FL).

Crucini, M. 1989, A two-country real business cycle model, Manuscript (Fconomics Department. University of Rochester, Rochester, NY).

Danthine, J.-P. and J. Donaldson, 1993, Methodological and empirical issues in real business cycle theory, European Economic Review 37, 1-35.

Dellas, H., 1986, A real model of the world business cycle, Journal of International Money and Finance 5, $381-394$

Devereux, M., A. Gregory, and G. Smith, 1992, Realistic cross-country consumption correlations in at two-country, equilibrium, business cycle model, Journal of International Money and Finance 11,316 .

Dunn, K. and K. Singleton, 1986, Modeling the term structure of interest rates under non-separable utility and durability of goods, Journal of Financial Economics 17, 27.55. 
Finn, M., 1990, On savings and investment dynamics in a small open economy, Journal of International Economics 29, 1-21.

Friend, 1. and M. Blume, 1975, The demand for risky assets, American Economic Review 65, 900-922.

Ghosh, A., 1990, International capital mobility and optimal current account behavior: An empirical investigation, Discussion paper no. 50 (Economics Department, Princeton University, Princeton, NY)

Glick, R. and K. Rogoff, 1992, Global versus country-specific productivity shocks and the current account, Working paper no. 4140 (National Bureau of Economic Research, Cambridge, MA).

Gomme, P., 1993, Money and growth revisited, Journal of Monetary Economics 32, 51-77.

Gregory, A. and G. Smith, 1991, Calibration and testing: Inferences in simulated macroeconomic models, Journal of Business and Economic Statistics 9, 297-303.

Grilli, V. and N. Roubini, 1991, Liquidity and exchange ratcs, Journal of International Economics $32,339-352$.

Hansen, G., 1985, Indivisible labor and the business cycle, Journal of Monetary Economics 16, 309-327.

Hansen, G. and R. Wright, 1992, The labor market in real business cycle theory, Federal Reserve Bank of Minneapolis Quarterly Review 16, 2-12.

Hansen, L. and K. Singleton, 1983, Stochastic consumption, risk aversion, and the temporal behavior of asset returns, Journal of Political Economy 91, 249-265.

Hodrick, R. and E. Prescott, 1980, Post-war U.S. business cycles: An empirical investigation, Working paper (Carnegie-Mellon University, Pittsburgh, PA).

Juster, T. and F. Stafford, 1991, The allocation of time: empirical findings, behavioral models, and problems of measurement, Journal of Economic Literature 29, 471-522.

King, R., C. Plosser, and S. Rebelo, 1988, Production, growth and business cycles, I. The basic neoclassical model, Journal of Monetary Economics 21, 196-232.

King, R., C. Plosser, and S. Rebelo, 1990, Production, growth, and business cycles: Technical appendix (revised version), Manuscript (Economics Department, University of Rochester, Rochester, NY).

Kollmann, R., 1991, Essays on international business cycles, Ph.D. dissertation (Economics Department, University of Chicago, Chicago, IL).

Kollmann, R., 1995, Consumptions, real exchange rates and the structure of international asset markets, Journal of International Money and Finance 14, 191-211.

Leiderman, L. and A. Razin, 1990, External balance dynamics: estimation under rational expectations, Manuscript (Tel-Aviv University, Tel-Aviv).

Leme, P., 1984, Integration of international capital markets, Manuscript (University of Chicago, Chicago, IL).

Macklem, T., 1993, Terms-of-trade disturbances and fiscal policy in a small open economy, Economic Journal 103, 911-936.

McCallum, B., 1989, Real business cycle models, in: R. Barro, ed., Modern business cycle theory (Harvard University Press, Cambridge, MA) 16-50.

McCurdy, T. and N. Ricketts, 1991, An international economy with country-specific money and productivity growth processes, Working paper (Economics Department, Queen's University, Kingston).

Mehra, R. and E. Prescott, 1985, The equity premium - A puzzle, Journal of Monetary Economics $15,145-162$.

Mendoza, E., 1991, Real business cycles in a small open economy, American Fconomic Review 81, $797-818$.

Musgrave, J., 1992, Fixed reproducible wealth in the United States, revised estimates, Survey of Current Business, Jan., 106-137. 
Obstfeld, M., 1993, Are industrial-country consumption risks globally diversified?, Working paper no. 4308 (National Bureau of Economic Research, Cambridge, MA).

Otto, G., 1992, Testing a present-value model of the current account: Evidence from US and Canadian time series, Journal of International Money and Finance 11, 414-430.

Prescott, E., 1986, Theory ahead of business cycle measurement, Federal Reserve Bank of Minneapolis Quarterly Review 10(4), 9-22.

Ravn, M. 1992, Business cycles in the II.K. A small open economy in an interdependent world. Manuscript (University of Aarhus, Aarhus).

Rebelo, S., 1988a, Heterogeneous agent economies, Manuscript (Economics Department, University of Rochester, Rochester, NY).

Rebelo, S., 1988b, Tractable heterogeneity and near steady state dynamics, Manuscript (Economics Department, University of Rochester, Rochester, NY).

Reynolds, P., 1992, International comovements in production and consumption: Theory and evidence, Manuscript (University of Southern California, Los Angeles, CA).

Rotemberg, J. and M. Woodford, 1989, Oligopolistic pricing and the effects of aggregate demand on economic activity, Working paper no. 3206 (National Bureau of Economic Research, Cambridge, MA).

Sargent, T., 1987, Macroeconomic theory, 2nd ed. (Academic Press, Boston, MA).

Scheinkman, J., 1984, General equilibrium models of economic fluctuations: A survey of theory. Manuscript (University of Chicago, Chicago, IL).

Schlagenhauf, D. and J. Wrase, 1992, A monetary, open-economy model with capital mobility, Discussion paper no. 67 (Institute for Empirical Macroeconomics. Federal Reserve Bank of Minneapolis, Minneapolis, MN).

Schmitt-Grohe, S., 1993, The international transmission of economic fluctuations: Effects of U.S. business cycles on the Canadian economy, Manuscript (Economic Department, University of Chicago, Chicago, IL).

Sheffrin, S. and W. Woo, 1990, Present value tests of an intertemporal model of the current account. Journal of International Economics 29, 237-253.

Solow, R.. 1957, Technical change and the aggregate production function, Review of Economics and Statistics 39, 312-320.

Stockman. A. and L. Tesar, 1990, Tastes and technology in a two-country model of the business cycle: Explaining international comovements, Manuscript (Economics Department, University of Rochester, Rochester, NY).

van Wincoop, E. and J. Marrinan, 1993, Public and private saving and investment, Manuscript (Boston University, Boston, MA).

Yi, K., 1993, Can government consumption explain the recent U.S. net exports deficits?., Journal of International Economics 35, 201-225. 